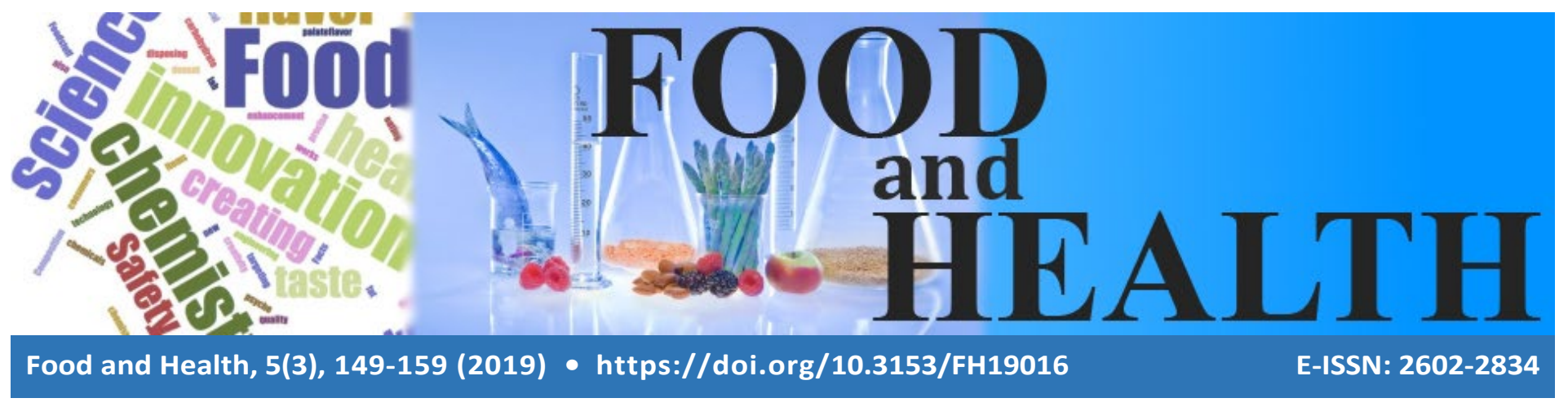

Research Article

\title{
IDENTIFICATION OF Staphylococcus aureus CHEESE ISOLATES WITH RESPECT TO VIRULENCE PROPERTIES, GENETIC RELATEDNESS AND ANTIBIOTIC RESISTANCE PROFILES
}

\author{
Pınar Kadiroğlu ${ }^{1} \oplus$, Figen Korel $^{2} \odot$, Çăgatay Ceylan² ${ }^{2}$
}

Cite this article as:

Kadiroğlu, P., Korel, F., Ceylan, Ç. (2019). Identification of Staphylococcus aureus cheese isolates with respect to virulence properties, genetic relatedness and antibiotic resistance profiles. Food and Health, 5(3), 149-159. https://doi.org/10.3153/FH19016

\footnotetext{
${ }^{1}$ Adana Science and Technology University, Food Engineering Department, 01250, Sarıçam, Adana, Turkey

2 İzmir Institute of Technology, Food Engineering Department, Urla, 35430, İzmir, Turkey
}

\section{ORCID IDs of the authors:}

P.K. 0000-0002-9730-8655

F.K. 0000-0001-8202-6797

Ç.C. 0000-0001-5254-5983

Submitted: 12.10 .2018

Accepted: 29.11.2018

Published online: 14.02 .2019

Correspondence:

Pınar KADİROĞLU

E-mail: pkadiroglu@adanabtu.edu.tr

๑) Copyright 2019 by ScientificWebJournals Available online at http://jfhs.scientificwebjournals.com

\begin{abstract}
The problems on identification of Staphylococcus aureus isolates from cheese samples were investigated by phenotypic and genotypic tests in this study. Among 207 Staphylococcus spp. isolated from 31 cheese samples, 23 isolates that were Gram positive, catalase and slide coagulase positive, with 1 isolate that was latex agglutination test negative showed different phenotypic properties. Polymerase chain reaction (PCR) and quantitative PCR (qPCR) analyses showed that DNase test and target genes (nuc, coa) regarded as gold standard regions for $S$. aureus were not found to be unique for identification of $S$. aureus. The toxin genes (SEA-SEE) were not detected by PCR. Antibiotic resistance profiles of $S$. aureus isolates demonstrated that two isolates were resistant to penicillin G. This study showed that the unique phenotypic and genotypic test was not adequate for identification of $S$. aureus isolates. There was no correlation between the presence of the nuc gene and toxin genes. The presence of nuc gene which was used for detection of $S$. aureus was also found to be present in other Staphylococcus isolates. As a conclusion, the results revealed that biochemical tests could lead to false positive results for identification of $S$. aureus. The presence of nuc gene is not correlated with the presence of toxin genes.
\end{abstract}

Keywords: Staphylococcus aureus, PCR, Identification, Antibiotic resistance 


\section{Introduction}

Staphylococcus aureus (S. aureus) is one of the most significant bacterial pathogens for human health and commonly involved in bacterial infections and food poisoning outbreaks worldwide (Chapaval et al., 2008; Ertas et al., 2010). Heat stable enterotoxins produced by specific strains of $S$. aureus are significant agents in staphylococcal food poisoning cases (Guven et al., 2010). The pathogenesis of S. aureus infection could be related to secretion of extracellular toxins and enzymes such as coagulase, DNase, thermonuclease etc (Kong et al., 2016). Milk and dairy products are pasteurized to eliminate high contamination levels of $S$. aureus; however, toxins produced by the bacterium are not inactivated in this process (Peles et al., 2007; Akineden et al., 2008). Several antibiotics are used to eliminate the diseases in animals and the bacterial intoxication cases. The common antibiotic use for treatment of animals and preservation of milk has caused development of antibiotic resistance (Alian et al., 2012).

Molecular methods can distinguish differences among closely related species as demonstrated by many researchers (Gičová et al., 2014; Villarreal et al., 2013; Kabadjova et al., 2002). Molecular methods can be used for identification of $S$. aureus to control the invasiveness of this bacterium among human, animal, and food (André et al., 2008). Surface proteins, invasions, toxins, biochemical properties, and inherent and acquired resistance to antimicrobial agents are the main virulence factors of $S$. aureus (Franklin and Lowy 1998; Stutz et al., 2011). Staphylococcal enterotoxins are the important virulence factors involved in pathogenicity of S. aureus (Huong et al., 2010). Staphylococcal food poisoning is caused by ingestion of foods contaminated with $S$. aureus that include one or more enterotoxins (Vasconcelos and Cunha 2010). Therefore, it is significant to detect and identify $S$. aureus in food samples. The presence of the nuc gene coding thermostable nuclease enzyme was used as an indication of $S$. aureus contamination in several studies (Alarcón et al., 2006; Aprodu et al., 2011; Hein et al., 2001; Lem et al., 2001). The nuc gene was used together with coa gene for identification of enterotoxigenic $S$. aureus strains by analyzing with PCR method (Cremonesi et al., 2007). PCR amplification of coa gene was regarded as a gold standard when compared to tube coagulase test (Tiwari et al., 2008). The genes encoding 23S rRNA, $16 \mathrm{~S}$ to $23 \mathrm{~S}$ rRNA spacer region, and $16 \mathrm{~S}$ rRNA were used to confirm the biochemical test results for identification of $S$. aureus (Akineden et al., 2008; Gomez et al., 2007; Phuektes et al., 2003).
The identification of $S$. aureus can be carried out inaccurately based on unique phenotypic or genotypic tests. Studies on $S$. aureus showed that there were some contradictory results on identification of $S$. aureus. The phenotypic and genotypic tests can lead to misidentification by the impact of environmental factors on gene expression (Gandra et al., 2005).

Although several studies have been reported on the isolation and identification of the isolated $S$. aureus strains from Turkey, there have been only limited numbers of studies on the investigation of this bacterium from western part of the country. Another distinguishing point in our study is the comprehensive evaluation of latex agglutination test, tube coagulase and DNase activity tests with the presence of nuc and coa genes. The main objective of this study is to carry out the molecular and biochemical identification of $S$. aureus strains isolated from white cheese samples from three different locations in western part of Turkey. In addition, antibiotic sensitivities and toxin production properties were also characterized. Genetic relatedness of the isolates was determined by sequencing of the $16 \mathrm{~S}$ rDNA region. Antibiotic resistance profiles of the isolates were obtained by performing the antibiotic susceptibility tests of the isolates to the 31 antibiotics and by searching the presence of mecA gene by PCR analysis.

\section{Materials and Methods}

\section{Isolation and Identification of Strains}

A total of 207 strains were purified from 31 unpackaged cheese samples purchased from local markets in western Turkey (cities of İzmir, Manisa, and Aydin). Twent five gram cheese samples were homogenized in $225 \mathrm{~mL}$ of sterile $0.1 \%$ buffered peptone water (Merck, Darmstadt, Germany). Serial dilutions were prepared up to $10^{-3}$ and $0.1 \mathrm{~mL}$ aliquots were plated on Baird-Parker agar (BD-Difco, Sparks, Maryland) supplemented with egg yolk tellurite (BD-BBL, Sparks, Maryland) and incubated at $37^{\circ} \mathrm{C}$ for 24 $48 \mathrm{~h}$. The typical and atypical bacterial colonies isolated from the incubated plates were transferred into tryptic soy broth medium for enrichment. The enriched bacteria were subcultured using streak plate technique. Gram staining, catalase, latex agglutination and tube coagulase, DNase activity and mannitol fermentation tests were performed. DNase activity test was performed by inoculating the culture to the DNase test agar and grown for $24 \mathrm{~h}$ at $37^{\circ} \mathrm{C} .37 \% \mathrm{HCl}$ solution was poured onto the colonies for 5 minutes and observed for the clear zone around the colonies. Coagulase test was performed in two ways as tube coagulase test and latex 
agglutination test. Latex agglutination test was carried out by using latex agglutination test kit. Tube coagulase test was performed for the determination of free coagulase production of the isolates, for this, coagulase plasma $(0.5 \mathrm{~mL})$ in the clean test tube was mixed with the tested isolate. The test tube was incubated at $37^{\circ} \mathrm{C}$ and observed every 30 minutes for clotting by gently shaking the tube (Sperber and Tatini, 1975; Kateete et al., 2010). All purified isolates were stored at $-80^{\circ} \mathrm{C}$ for further analysis. S. aureus RSKK 1009 was used as positive control in the study.

\section{Bacterial DNA Extraction}

Overnight tryptic soy broth culture $(0.2 \mathrm{~mL})$ of each isolate was transferred to eppendorf tubes and centrifuged at 15.000 $\mathrm{x} g$ for $5 \mathrm{~min}$. The pellet was homogenized with $45 \mu \mathrm{L}$ of sterile deionized water. The cells were treated with lysostaphin $\left(100 \mu \mathrm{g} \mathrm{mL}^{-1}\right)$ and incubated at $37^{\circ} \mathrm{C}$ for $1 \mathrm{~h}$. Following this, $15 \mu \mathrm{L}$ of proteinase $\mathrm{K}\left(100 \mu \mathrm{g} \mathrm{mL}^{-1}\right)$ and 150 $\mu \mathrm{L}$ of Tris- $\mathrm{HCl}(0.1 \mathrm{M}, \mathrm{pH} 7.5)$ were added. Cell suspensions were incubated at $37^{\circ} \mathrm{C}$ for $1 \mathrm{~h}$ and subsequently held in boiling water for $5 \mathrm{~min}$. These cell lysates were stored at $-20^{\circ} \mathrm{C}$ (Sudagidan et al., 2008).

\section{Quantitative PCR Analysis}

The primers and probe targeting $\underline{\text { nuc }}$ gene were used as reported by Alarcón et al. (2006). The TaqMan probe was la- beled with 6-carboxy-fluorescein (FAM) and with 6-carboxy-tetramethyl-rhodamine (TAMRA) in $5^{\prime}$ and $3^{\prime}$ ends, respectively. The size of the amplified $\underline{n u c}$ gene product was expected to be $124 \mathrm{bp}$ in length. Amplification assay of TaqMan based qPCR included in a total volume of $20 \mu \mathrm{L}$. This mixture composed of $10 \mathrm{X}$ probes master, $500 \mathrm{nM}$ of each primer, $200 \mathrm{nM}$ probe and $5 \mu \mathrm{L}$ of template DNA. The thermal cycling programme started with $95^{\circ} \mathrm{C}$ for $10 \mathrm{~min}$ of incubation. 50 cycles of amplification included $95^{\circ} \mathrm{C}$ for $15 \mathrm{~s}$ denaturation step, annealing at $60^{\circ} \mathrm{C}$ for TaqMan probe. The reaction ended with extention step at $72^{\circ} \mathrm{C}$ for $1 \mathrm{~s}$. The data analyses were carried out using LightCycler ${ }^{\circledR} 480$ Instrument software version 1.5 (Roche Diagnostics, Basel, Switzerland).

\section{PCR Amplification of the Targeted Genomic Loci}

S. aureus strains were genotyped by PCR amplification targeting 23S rDNA (Straub et al., 1999), the spacer region between 16S-23S (Forsman et al., 1997), clumping factor (clfA), $\mathrm{X}$ and $\mathrm{IgG}$ binding regions of the protein $\mathrm{A}$ and $c o-$ agulase (coa) using the PCR as described previously (Akineden et al., 2008). femA and sau regions were used as internal amplification controls in PCR analyses (Mehrotra et al., 2000; Holochová et al., 2010). PCR programme of amplification was given in Table 1.

Table 1. PCR amplification conditions

\begin{tabular}{|c|c|}
\hline Target gene & Amplification Program \\
\hline $23 \mathrm{~S}$ rDNA & $\begin{array}{l}\text { Pre-denaturation } 5 \mathrm{~min} \text { at } 94^{\circ} \mathrm{C}, 37 \text { cycles of denaturation at } 94^{\circ} \mathrm{C} \text { for } 40 \mathrm{~s} \text {, annealing at } \\
64^{\circ} \mathrm{C} \text { for } 60 \mathrm{~s} \text {, extension at } 72^{\circ} \mathrm{C} \text { for } 75 \mathrm{~s} \text { and a final extension of } 3.5 \mathrm{~min} \text { at } 72^{\circ} \mathrm{C} \text {. }\end{array}$ \\
\hline $16 \mathrm{~S}-23 \mathrm{~S}$ rDNA & $\begin{array}{l}\text { Pre-denaturation } 5 \mathrm{~min} \text { at } 94^{\circ} \mathrm{C}, 30 \text { cycles of denaturation at } 94^{\circ} \mathrm{C} \text { for } 30 \mathrm{~s} \text {, annealing at } \\
55^{\circ} \mathrm{C} \text { for } 30 \mathrm{~s} \text {, extension at } 72^{\circ} \mathrm{C} \text { for } 30 \mathrm{~s} \text { and a final extension of } 3.5 \mathrm{~min} \text { at } 72^{\circ} \mathrm{C} \text {. }\end{array}$ \\
\hline $\operatorname{Clf} A$ & $\begin{array}{l}\text { Pre-denaturation } 5 \mathrm{~min} \text { at } 94^{\circ} \mathrm{C}, 35 \text { cycles of denaturation at } 94^{\circ} \mathrm{C} \text { for } 60 \mathrm{~s} \text {, annealing at } \\
57^{\circ} \mathrm{C} \text { for } 60 \mathrm{~s} \text {, extension at } 72^{\circ} \mathrm{C} \text { for } 60 \mathrm{~s} \text { and a final extension of } 3.5 \mathrm{~min} \text { at } 72^{\circ} \mathrm{C} \text {. }\end{array}$ \\
\hline$N u c$ & $\begin{array}{l}\text { Pre-denaturation } 5 \mathrm{~min} \text { at } 94^{\circ} \mathrm{C}, 37 \text { cycles of denaturation at } 94^{\circ} \mathrm{C} \text { for } 1 \mathrm{~min} \text {, annealing } \\
\text { at } 55^{\circ} \mathrm{C} \text { for } 30 \mathrm{~s} \text {, extension at } 72^{\circ} \mathrm{C} \text { for } 30 \mathrm{sec} \text { and a final extension of } 3.5 \mathrm{~min} \text { at } 72^{\circ} \mathrm{C} \text {. }\end{array}$ \\
\hline Coa, Spa Igg & $\begin{array}{l}\text { Pre-denaturation } 5 \text { min at } 94^{\circ} \mathrm{C}, 30 \text { cycles of denaturation at } 94^{\circ} \mathrm{C} \text { for } 60 \mathrm{~s} \text {, annealing at } \\
58^{\circ} \mathrm{C} \text { for } 60 \mathrm{~s} \text {, extension at } 72^{\circ} \mathrm{C} \text { for } 60 \mathrm{~s} \text { and a final extension of } 3.5 \mathrm{~min} \text { at } 72^{\circ} \mathrm{C} \text {. }\end{array}$ \\
\hline $\operatorname{Spa} X$ & $\begin{array}{l}\text { Pre-denaturation } 5 \mathrm{~min} \text { at } 94^{\circ} \mathrm{C}, 30 \text { cycles of denaturation at } 94^{\circ} \mathrm{C} \text { for } 60 \mathrm{~s} \text {, annealing at } \\
60^{\circ} \mathrm{C} \text { for } 60 \mathrm{~s} \text {, extension at } 72^{\circ} \mathrm{C} \text { for } 60 \mathrm{~s} \text { and a final extension of } 3.5 \mathrm{~min} \text { at } 72^{\circ} \mathrm{C} \text {. }\end{array}$ \\
\hline femA & $\begin{array}{l}\text { Pre-denaturation } 5 \mathrm{~min} \text { at } 94^{\circ} \mathrm{C}, 35 \text { cycles of denaturation at } 94^{\circ} \mathrm{C} \text { for } 2 \mathrm{~min} \text {, annealing } \\
\text { at } 57^{\circ} \mathrm{C} \text { for } 2 \mathrm{~min} \text {, extension at } 72^{\circ} \mathrm{C} \text { for } 60 \mathrm{~s} \text { and a final extension of } 7 \mathrm{~min} \text { at } 72^{\circ} \mathrm{C} \text {. }\end{array}$ \\
\hline Sau & $\begin{array}{l}\text { Pre-denaturation } 3 \mathrm{~min} \text { at } 94^{\circ} \mathrm{C}, 30 \text { cycles of denaturation at } 94^{\circ} \mathrm{C} \text { for } 45 \mathrm{~s} \text {, annealing at } \\
56^{\circ} \mathrm{C} \text { for } 60 \mathrm{~s} \text {, extension at } 72^{\circ} \mathrm{C} \text { for } 90 \mathrm{~s} \text { and a final extension of } 7 \mathrm{~min} \text { at } 72^{\circ} \mathrm{C} \text {. }\end{array}$ \\
\hline
\end{tabular}




\section{Detection of Toxin Production and Toxin Genes in S. aureus Strains}

Enterotoxin production was investigated for all $S$. aureus strains isolated using SET-RPLA Toxin kit (Oxoid, Hampshire, UK) according to manufacturer's instructions. The enterotoxin genes (SEA-SEE) were amplified using the primers reported previously (Akineden et al., 2008). S. aureus reference strains with SEA (619/93), SEB (62/92), SEC (1229/93), SED (1644/93), SEE (FRI 918) were used as toxin positive controls. The PCR program was performed following 30 cycles of $94^{\circ} \mathrm{C}$ for $5 \mathrm{~min}, 94^{\circ} \mathrm{C}$ for $120 \mathrm{sec}$, $55^{\circ} \mathrm{C}$ annealing temperature for toxins $\mathrm{A}, \mathrm{B}$ and $\mathrm{E}, 50^{\circ} \mathrm{C}$ annealing temperature for toxins $\mathrm{C}$ and $\mathrm{D}, 72{ }^{\circ} \mathrm{C}$ for 60 and final extension of $72^{\circ} \mathrm{C}$ for $3.5 \mathrm{~min}$. The amplification was carried out with thermal cycler (Bio-Rad, California, USA).

\section{Antimicrobial Disc Susceptibility Test and Detection of mecA Gene}

The isolates were tested for antibiotic susceptibility using agar disc diffusion method using Mueller Hinton agar according to the Clinical and Laboratory Standards Institute (CLSI 2006). The antibiotics included were amoxycillin/clavulanate, ampicillin/sublactam, cefoxitin, cephazolin, clindamycin, chloramphenicol, ciprofloxacin, clarithromycin, fusidic acid, gentamycin, imipenem, kanamycin, levofloxacin, linezolid, moxifloxacin, neomycin, norfloxacin, ofloxacin, oxacillin, penicillin $\mathrm{G}$, piperacillin/tazobactam, quinupristin/dalfopristin, rifampicin, teicoplanin, tetracycline, ticarcillin/clavulanate, tigecycline, tobramycin, trimethoprim-sulfamethazole, vancomycin, enrofloxacin (Oxoid, Hampshire, United Kingdom). Twenty of the antibiotics were in the critically important, 7 were selected from highly important, 4 antibiotics were selected from important class of antibiotics. The inhibition zone diameters were classified susceptible, intermediate or resistant according to CLSI (2006) and Comite de'Antibiogramm de la Societe Francaise de Microbiologie (for fusidic acid) (2001). The primers and PCR method given by Lem et al. (2001) were used for the detection of methicillin resistance gene ( $m e c A)$. PCR consisted of 40 cycles starting with an initial incubation of $95^{\circ} \mathrm{C}$ for $5 \mathrm{~min}$ followed by $95^{\circ} \mathrm{C}$ for $20 \mathrm{sec}, 63^{\circ} \mathrm{C}$ for $45 \mathrm{sec}$ annealing, $72^{\circ} \mathrm{C}$ for $45 \mathrm{sec}$ extension and final incubation of $72^{\circ} \mathrm{C}$ for $5 \mathrm{~min}$.

\section{Sequence Analysis}

The bacterial strains were identified by using the primers amplifying $350 \mathrm{bp}$ fragment of $16 \mathrm{~S}$ ribosomal DNA gene. The primers were: Forward primer: 5' AGAGTTTGATCCTGGCTCAG-3' Reverse primer: 5'CCCACTGCTGCCTCCCGTAG-3'
The reaction conditions and primers were used as described by Riyaz-Ul-Hassan et al. (2008). The amplified products were purified and sequenced with Genetic Analyzer 3130 XL (Applied Biosytems, California, USA). One forward primer was used for sequencing. The sequences obtained were compared with the sequences in the NCBI database with BLAST Analysis. The sequences were aligned with ClustalW program adapted to Mega 5.2 program (Tamura et al. 2011). Phylogenetic distance tree was constructed with Maximum Likelihood method with phylogency test of Bootstrap method with 1000 replications to investigate the similarity between different isolates.

\section{Results and Discussion}

\section{Identification of the Isolates}

Due to the importance of the $S$. aureus as an important foodborne pathogen, it is necessary to characterize $S$. aureus strains isolated from white cheese samples and to investigate these strains by toxin typing. For this purpose 207 strains were obtained from 31 different cheese samples. Twenty four (24) isolates that were Gram positive and catalase positive and gave at least one positive reaction to DNase activity, mannitol fermentation and latex agglutination tests were further investigated for the presence of $c o a$ and nuc genes and sequence analyses. The presence of nuc gene was examined with qPCR analysis. A total of 3 of the isolates were identified as $S$. aureus according to all biochemical test, PCR, qPCR and sequence analysis results with higher than 93\% sequence identity. The test results of the isolates to these analyses are given in Table 2.

Previously, it was reported that there is no single test that can definitely identify $S$. aureus (Kateete et al., 2010). Biochemical tests are not enough for reliable identification of $S$. aureus strains. For this reason both biochemical and genetic tests were carried out for correct identification of the isolated strains. Comparative analyses such as latex agglutination test, tube coagulase test, and coa and $n u c$ gene presence were examined to choose the gold standard method for identification of $S$. aureus. Tube coagulase test has been used for differentiation of S.aureus in most of the studies (Malathi et al., 2009; Akineden et al., 2011). In one of these studies; latex agglutination test, Slidex Staph plus test and tube coagulase test were compared. Analysing the presence of coa gene by PCR was used as a gold standard for detection of $S$. aureus and tube coagulase test was recommended as routine test to correctly differentiate $S$. aureus from coagulase negative staphylococci (Tiwari et al., 2008). However, it is important that coagulase negative strains of $S$. aureus have also been reported. In these studies, the isolates gave negative reaction to tube coagulase test, but they all carried coa gene 
when amplified with PCR (Vandenesch et al., 1994; Akineden et al., 2011).

qPCR amplification of $n u c$ gene has been used as a gold standard for the detection of S.aureus in many studies (Hein et al., 2001, Alarcón et al., 2006, Esan et al., 2009). The nuc gene was reported to have $S$. aureus species specific sequences (Asfour and Darwish, 2011). In this study, the results showed that 3 isolates $(16,20,21)$ identified as Staphylococcus spp. that tested negative in tube coagulase test were positive for the coa gene. Also 2 of the isolates (15, 20) that were tube coagulase negative had the nuc gene. These isolates gave positive reaction to latex agglutination test.

The isolates harbouring the $n u c$ gene could not be identified as $S$. aureus by sequence analyses. The common property of these isolates was that they did not show DNase activity. The sequence analyses were performed to investigate the genetic similarity of the isolates using $16 \mathrm{~S}$ rDNA gene sequences. The distance tree showing the genetic relatedness of the isolates is given in Figure 1. But there were no definite clusters among the $S$. aureus isolates and other isolates. The isolates 1, 3, 4, 5 and S. aureus RSKK 1009 which was used as positive control (PC) were found closer to each other under the same branch of the tree. The isolate 18 which was sequenced as $S$. carnosus was grouped with $S$. hyicus and $S$. intermedius apart from the other isolates.

\section{Virulence Properties of the Isolates}

The virulence properties of $S$. aureus isolates were investigated by PCR analysis. Several target regions including the 23S rDNA, the spacer region between 16S-23S rDNA, coa, clf, spaX, and spaIgG were amplified in the bacterial genome using PCR method. Sau and femA regions were used as internal controls in several studies for confirmation of the presence of $S$. aureus (Mehrotra et al., 2000; Holochová et al., 2010). The results of the PCR experiments are given in Table 3 . As the results indicated, except for $16 \mathrm{~S}-23 \mathrm{~S}$ region, all of the target regions tested positive to the isolated strains. Also, in correlation to our study, 5 of the 64 isolates which were confirmed as $S$. aureus tested negative for the $16 \mathrm{~S}-23 \mathrm{~S}$ rDNA intergenic spacer region in a previous study (Akineden et al., 2008).

Table 2. Biochemical test results, PCR, $\mathrm{qPCR}$ and sequence analyses results of the isolates.

\begin{tabular}{|c|c|c|c|c|c|c|c|c|c|}
\hline $\begin{array}{c}\text { Sample } \\
\text { code }\end{array}$ & $\begin{array}{c}\text { Gram } \\
\text { staining }\end{array}$ & $\begin{array}{c}\text { Catalase } \\
\text { test }\end{array}$ & $\begin{array}{c}\text { Latex } \\
\text { agglutination } \\
\text { test }\end{array}$ & $\begin{array}{c}\text { DNase } \\
\text { activity }\end{array}$ & $\begin{array}{c}\text { Mannitol } \\
\text { ferm. }\end{array}$ & $\begin{array}{c}\text { Tube } \\
\text { coagulase } \\
\text { test }\end{array}$ & coa & nuc & Sequence \\
\hline $\mathrm{PC}$ & + & + & + & + & + & + & + & + & S. aureus $(97 \%)$ \\
\hline 1 & + & + & + & + & + & + & + & + & S. aureus $(94 \%)$ \\
\hline 2 & + & + & + & + & + & + & + & + & S. aureus $(98 \%)$ \\
\hline 3 & + & + & + & + & + & + & + & + & S. aureus $(90 \%)$ \\
\hline 4 & + & + & + & - & + & + & + & + & S.pasteuri $(85 \%)$ \\
\hline 5 & + & + & + & - & + & + & + & + & S.saprophyticus (83\%) \\
\hline 6 & + & + & + & - & - & - & - & - & Staphylococcus spp.(97\%) \\
\hline 7 & + & + & - & - & + & - & - & - & S. epidermidis $(99 \%)$ \\
\hline 8 & + & + & + & - & - & - & - & - & Macrococcus spp. (92\%) \\
\hline 9 & + & + & + & - & - & - & - & - & Staphylococcus spp.(87\%) \\
\hline 10 & + & + & + & - & - & - & - & - & Staphylococcus spp.(93\%) \\
\hline 11 & + & + & + & + & - & - & - & - & S. carnosus $(86 \%)$ \\
\hline 12 & + & + & + & + & - & - & - & - & S. carnosus $(99 \%)$ \\
\hline 13 & + & + & + & - & + & - & - & - & S. aureus $(83 \%)$ \\
\hline 14 & + & + & + & - & - & - & - & - & S.carnosus $(85 \%)$ \\
\hline 15 & + & + & + & - & + & - & - & + & S. xylosus $(88 \%)$ \\
\hline 16 & + & + & + & - & - & - & + & - & Uncultured bacterium (91\%) \\
\hline 17 & + & + & + & + & + & - & - & - & S. sciuri $(83 \%)$ \\
\hline 18 & + & + & + & - & + & - & - & - & S. carnosus $(81 \%)$ \\
\hline 19 & + & + & + & - & + & - & - & - & S. saprophyticus $(86 \%)$ \\
\hline 20 & + & + & + & - & + & - & + & + & S. equorum $(81 \%)$ \\
\hline 21 & + & + & + & - & - & - & + & - & S. carnosus $(99 \%)$ \\
\hline 22 & + & + & + & - & + & - & - & - & S. xylosus $(98 \%)$ \\
\hline 23 & + & + & + & - & + & - & - & - & S. saprohyticus (88\%) \\
\hline 24 & + & + & + & + & + & - & - & - & Staphylococcus spp. (84\%) \\
\hline
\end{tabular}

PC: Positive control (S. aureus RSKK 1009) 


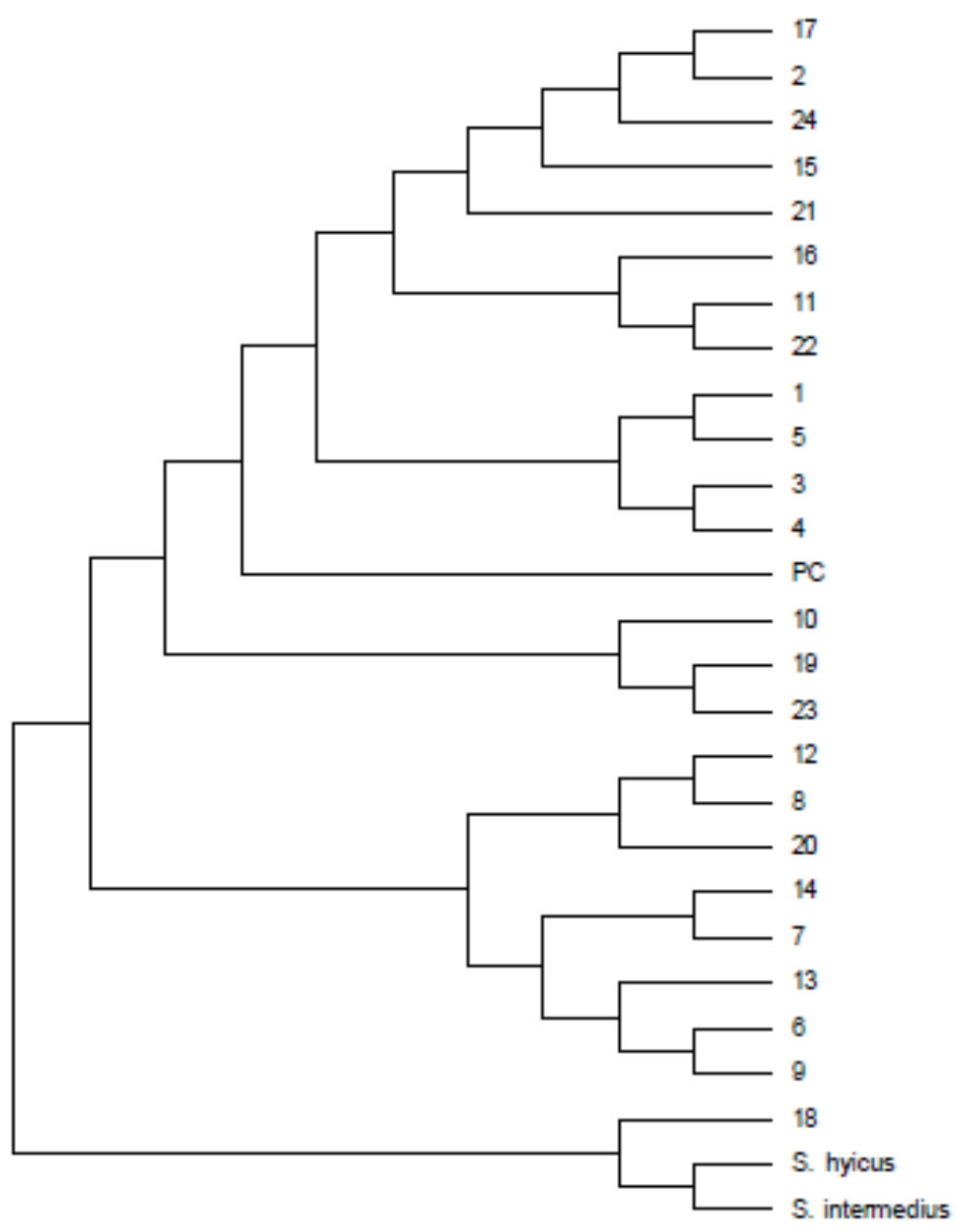

Figure 1. Genetic relatedness of Staphylococcus isolates

\section{Toxin Production Ability of the Isolates}

The presence of the enterotoxin genes were also investigated by application of PCR targeting SEA, SEB, SEC, SED and SEE, but none of the strains were found to contain these toxin genes in their genomes. This result was in accordance with the results obtained using the toxin detection kit.

Staphylococcus strains produce thermonuclease that degrades both DNA and RNA. The nuc gene encoding thermonuclease protein has species-specific sequences (Brakstad et al., 1992). Detection of toxin genes does not necessarily indicate that the organism produces biologically active molecules or toxins. In a food system, PCR detection of toxin genes coupled with the specific detection of the producing species (nuc-PCR) represents the potential of toxin formation in food and hazardous food products due to the level of contamination (Ercolini et al., 2004). In this study, the correlation between the presence of $n u c$ gene and toxin genes was not found. The production of toxins was also tested by toxin test kit, but the results were in accordance with the PCR analyses of toxin genes.

\section{Antibiotic Resistance Profiles of the Isolates}

Antibiotic resistance is an important issue for transmission of $S$. aureus isolates to humans and the use of antibiotics as therapeutic purposes or growth promoters in animal husbandry (Alian et al., 2012). In this study, susceptibilities of the 3 isolates to 31 different antibiotics were investigated by agar disc diffusion method. Antibiotic resistance profiles of these isolates are shown in Table 4. All of the isolates were found to be susceptible to amoxycillin, ampicillin, cephazolin, chloramphenicol, ciprofloxacin, clindamycin, gentamycin, imipenem, kanamycin, levofloxacin, linezolid, ofloxacin, oxacillin, rifampicin, teicoplanin, tetracycline, tobramycin, trimethoprim-sulfamethazole, vancomycin, en- 
rofloxacin. In our study, it was found that $2(2,3)$ of the isolates were found to be resistant to Penicillin G. This can be related to the common use of penicillin for treatment of infections in humans and animals (Yucel et al., 2011). One isolate (1) showed intermediate resistance to fusidic acid. Similarly Sudagidan et al. (2010) investigated the antibiotic susceptibilites of $S$. aureus strains isolated from 1070 food samples and found that most of the strains were resistant to penicillin $\mathrm{G}$ from the samples collected from Marmara region of Turkey. In another study, antibiotic resistance tests of $138 \mathrm{~S}$. aureus strains isolated from 413 food samples obtained from Eskisehir and Kütahya provinces in Turkey illustrated that many of the strains showed high resistance to penicillin $\mathrm{G}$ (Guven et al., 2010).

Table 3. PCR analysis results of $S$. aureus isolates.

\begin{tabular}{ccccccccc}
\hline Sample code no & 23S rDNA & 16S-23S & coa & clf & spa $\boldsymbol{X}$ & spa Igg & fem A & sau \\
\hline 1 & + & - & + & + & + & + & + & + \\
2 & + & - & + & + & + & + & + & + \\
3 & + & - & + & + & + & + & + & + \\
PC & + & + & + & + & + & + & + & + \\
\hline
\end{tabular}

PC: Positive control (S. aureus RSKK 1009)

Table 4.Antibiotic resistance profiles of $S$. aureus isolates.

\begin{tabular}{|c|c|c|c|c|c|c|c|}
\hline \multirow[b]{2}{*}{ Antibiotics Name } & \multirow[b]{2}{*}{ Code } & \multicolumn{3}{|c|}{ Isolates } & \multicolumn{3}{|c|}{ Zone diameters } \\
\hline & & 1 & 2 & 3 & $\mathbf{R}$ & I & $\mathbf{S}$ \\
\hline Amoxycillin/clavulanate & AMC30 & 43 & 29 & 30 & $\leq 19$ & & $\geq 20$ \\
\hline Ampicillin/sublactam & SAM20 & 40 & 20 & 25 & $\leq 11$ & $12-14$ & $\geq 15$ \\
\hline Cefoxitin & FOX30 & 33 & 33 & 33 & $\leq 21$ & & $\geq 22$ \\
\hline Cephazolin & KZ30 & 38 & 35 & 27 & $\leq 14$ & $15-17$ & $\geq 18$ \\
\hline Chloramphenicol & $\mathrm{C} 30$ & 31 & 25 & 29 & $\leq 12$ & $13-16$ & $\geq 17$ \\
\hline Ciprofloxacin & CIP5 & 33 & 32 & 31 & $\leq 15$ & $16-18$ & $\geq 19$ \\
\hline Clarithromycin & CLR15 & 34 & 28 & 29 & $\leq 13$ & $14-17$ & $\geq 18$ \\
\hline Clindamycin & DA2 & 35 & 29 & 28 & $\leq 14$ & $15-20$ & $\geq 21$ \\
\hline Fusidic acid & FD10 & 20 & 32 & 34 & $\leq 15$ & $16-21$ & \\
\hline Gentamycin & CN120 & 40 & 31 & 31 & $\leq 12$ & $13-14$ & \\
\hline İmipenem & IPM10 & 51 & 50 & 52 & $\leq 13$ & $14-15$ & \\
\hline Kanamycin & K30 & 33 & 24 & 25 & $\leq 13$ & $14-17$ & \\
\hline Levofloxacin & LEV5 & 31 & 33 & 33 & $\leq 15$ & $16-18$ & \\
\hline Linezolid & LZD30 & 36 & 31 & 33 & & & $\geq 21$ \\
\hline Moxifloxacin & MXF5 & 33 & 34 & 35 & $\leq 20$ & $21-23$ & $\geq 24$ \\
\hline Neomycin & N30 & 30 & 23 & 24 & & & \\
\hline Norfloxacin & NOR10 & 29 & 30 & 30 & $\leq 12$ & $13-16$ & $\geq 17$ \\
\hline Ofloxacin & OFX5 & 28 & 31 & 30 & & & \\
\hline Oxacillin & OX1 & 13 & 24 & 26 & $\leq 10$ & $11-12$ & $\geq 13$ \\
\hline Penicillin G & $\mathrm{P} 10$ & 33 & 21 & 22 & $\leq 28$ & & $\geq 29$ \\
\hline Piperacillin/tazobactam & TZP110 & 38 & 27 & 27 & $\leq 17$ & & $\geq 18$ \\
\hline Quinupristin/dalfopristin & QD15 & 33 & 27 & 28 & $\leq 15$ & $16-18$ & $\geq 19$ \\
\hline Rifampicin & RD5 & 40 & 33 & 35 & $\leq 10$ & $17-19$ & $\geq 20$ \\
\hline Teicoplanin & TEC30 & 21 & 19 & 20 & $\leq 10$ & $11-13$ & $\geq 14$ \\
\hline Tetracycline & TE30 & 43 & 34 & 35 & $\leq 14$ & $15-18$ & $\geq 19$ \\
\hline Ticarcillin/clavulanate & TIM85 & 35 & 34 & 33 & $\leq 22$ & & $\geq 23$ \\
\hline Tigecycline & TGC15 & 36 & 28 & 30 & & & $\geq 20$ \\
\hline Tobramycin & TOB10 & 34 & 24 & 25 & $\leq 12$ & $13-14$ & $\geq 15$ \\
\hline Trimethoprim-sulfamethazole & SXT25 & 37 & 33 & 34 & $\leq 10$ & $11-15$ & $\geq 16$ \\
\hline Vancomycin & VA30 & 23 & 20 & 21 & & & $\geq 15$ \\
\hline Enrofloxacin & ENR5 & 31 & 33 & 33 & $\leq 13$ & $14-22$ & \\
\hline
\end{tabular}

R: Resistant I: Intermediate Resistance S: Susceptible zone diameter standards reported by Clinical and Laboratory Standards Institute. 
As reported by Alian et al. (2012), S. aureus strains isolated from milk samples were most commonly resistant to ampicillin $(54.3 \%)$, followed by oxacillin $(28.3 \%)$, tetracycline (26.1\%), penicillin G (23.9\%), erythromycin (23.9\%), trimethoprim-sulfamethoxazole $(17.4 \%)$ and cephalotin $(2.2 \%)$. It was evident that the isolates were resistant to $\beta$ lactams which were in accordance with our findings. Miranda et al. (2009) investigated the antibiotic resistance profiles of $S$. aureus isolated from conventional and organic cheeses and concluded that raw and pasteurized milk conventional cheese samples showed higher levels than pasteurized milk organic cheese samples for ciprofloxacin, penicillin, oxacillin and rifampicin. MecA gene that is highly conserved in methicillin resistant $S$. aureus strains provides resistance to methicillin and all other B-lactam antibiotics (Chambers, 1997). The susceptibility results to oxacillin, vancomycin, and erythromycin in the disc diffusion test were supported by PCR analysis of mecA gene which reveals that none of the isolates were resistant to methicillin.

\section{Conclusions}

The results indicated that the target genes (coa, nuc) that were regarded as gold standard regions for $S$. aureus were not found to be unique for the identification of $S$. aureus. The DNase activity which was used as a discriminatory test for $S$. aureus was not unique to $S$. aureus isolates. In addition, this study revealed that the presence of $n u c$ gene did not correlate with the DNase activity. No correlation was observed between the nuc gene and enterotoxigenecity. Three isolates were confirmed as $S$. aureus by using phenotypic tests, genotypic tests, and sequencing. These isolates were found to be resistant to Penicillin G only with slight resistance to fusidic acid. In conclusion, sequencing of the ribosomal DNA solely and only using phenotypic tests in the identification of $S$. aureus was not enough for correct identification of the isolates. In order to identify correctly all the genetic and phenotypic markers should be evaluated together.

\section{Compliance with Ethical Standard}

Conflict of interests: The authors declare that for this article they have no actual, potential or perceived the conflict of interests.

Financial disclosure: This research was supported by the Research Funds of Izmir Institute of Technology (Projects no 2012IYTE-10 and 2012-IYTE-12).

Acknowledgements: We acknowledge Izmir Institute of Technology, Biotechnology and Bioengineering Research and Application Center for their assistance during PCR analyses. We also acknowledge Dr. Ömer Akineden (Justus-Liebeg-Universität Gießen) for providing toxin positive control strains.

\section{References}

Akineden, Ö., Hassan, A.A., Schneider, E., Usleber, E. (2008). Enterotoxigenic properties of Staphylococcus aureus isolated from goats' milk cheese. International Journal of Food Microbiology, 124, 211-216.

Akineden, Ö., Hassan, A.A., Schneider, E., Usleber, E. (2011). A coagulase-negative variant of Staphylococcus aureus from bovine mastitis milk. Journal of Dairy Research, 78, 38-42.

Alarcón, B., Vicedo, B., Aznar, R. (2006). PCR-based procedures for detection and quantification of Staphylococcus aureus and their application in food. The Society of Applied Microbiology, Journal of Applied Microbiology, 100, 352-364.

Alian, F., Rahimi, E., Shakerian, A., Momtaz, H., Riahi, M., Momeni, M. (2012). Antimicrobial resistance of Staphylococcus aureus isolated from bovine, sheep and goat raw milk. Global Veterinaria, 8, 111-114.

André, C.M.D.P.B., Campos, M.R.H., Borges, L.J., Kipnis, A., Pimenta, F.C., Serafini, A.B. (2008). Comparison of Staphylococcus aureus isolates from food handlers, raw bovine milk and Minas Frescal cheese by antibiogram and pulsed-field gel electrophoresis following SmaI digestion. Food Control, 19, 200-207.

Aprodu, I., Walcher, G., Schelin, J., Hein, I., Norling, B., Rådström, P., Nicolau, A., Wagner, M. (2011). Advanced sample preparation for the molecular quantification of Staphylococcus aureus in artificially and naturally contaminated milk. International Journal of Food Microbiology, 145, 61-65.

Asfour, H.A.E., Darwish, S. H. (2011). Phenotypic and genotypic detection of both $\underline{m e c A}$ and blaZ genes mediated $\beta$-lactam resistance in Staphylococcus strains isolated from bovine mastitis. Global Veterineria, 6, 39-50.

Brakstad, O.G, Aasbakk, K., Maeland, J.A. (1992). Detection of Staphylococcus aureus by polymerase chain reaction amplification of the $\underline{n u c}$ gene. Journal of Clinical Microbiology, 30, 1654-1660.

Chapaval, L., Moon, D.H., Gomes, J.E., Duarte, F.R., Tsai, S.M. (2008). An alternative method for Staphylococcus aureus DNA isolation. Arquivo Brasileiro Medicina Veterinária e Zootecnia, 60, 299-306. 
Chambers H.F. (1997). Methicillin resistance in staphylococci: molecular and biochemical basis and clinical implications. Clinical Microbiology Reviews, 10(4), 781791.

CLSI (Clinical Laboratory Standards Institute). (2006). Performance Standards for Antimicrobial disc susceptibility testing, sixth ed. Pennsylvania, USA, p 188.

Comite de'Antibiogramm de la Societe Francaise de Microbiologie Report (2000-2001). (2001). MIC and zone diameter interpretive standards and interpretive reading rules for Staphylococcus spp., Paris.

Cremonesi, P., Perez, G., Pisoni, G., Moroni, P., Morandi, S., Luzzana, M., Brasca, M., Castiglioni, B. (2007). Detection of enterotoxigenic Staphylococcus aureus isolates in raw milk cheese. The Society of Applied Microbiology, Letters in Applied Microbiology, 45, 586591.

Ercolini, D., Blaiotta, G., Fusco, V., Coppola, S. (2004). PCR-based detection of enterotoxigenic Staphylococcus aureus in the early stages of raw milk cheese making. Journal of Applied Microbiology, 96, 1090-1096.

Ertas, N., Gonulalan, Z., Yildirim, Y., Kum, E. (2010). Detection of Staphylococcus aureus enterotoxins in sheep cheese and dairy desserts by multiplex PCR technique International Journal of Food Microbiology, 142, 7477.

Esan, C.O., Famurewa, O., Lin, J., Shittu, A.O. (2009). Characterization of Staphylococcus aureus isolates obtained from health care institutions in Ekiti and Ondo States, South-Western Nigeria. African Journal of Microbiology Research, 3, 962-968.

Forsman, P., Tissala-Timisjärvi, A., Alatossava, T. (1997). Identification of staphylococcal and streptococcal causes of bovine mastitis using 16S-23S rRNA spacer regions. Microbiology, 143, 3491-3500.

Franklin, D., Lowy, M.D. (1998). Staphylococcus aureus infections. The New England Journal of Medicine, 339, 520-532.

Gandra, E.Á., Silva, J.A., Macedo, M.R.P., Araújo M.R., Mata, M.M., Silva, W.P. (2005). Differentiation be- tween Staphylococcus aureus, S. intermedius and S. hyicus using phenotypical tests and PCR. Alimentos e Nutrição Araraquara, 16, 99-103.

Gičová, A., Oriešková, M., Oslanecová, L., Drahovská, H., Kaclíková, E. (2014). Identification and characterization of Cronobacter strains isolated from powdered infant foods. Letters in Applied Microbiology, 58, 242247.

Gomez, C., Pinal, L., Franco, J., Carrillo, J.M., Ramírez, J. (2007). Identification of Staphylococcus aureus strains negative for enterotoxins $\mathrm{A}, \mathrm{B}$ and $\mathrm{C}$ isolated from bovine mastitis in México. Veterinary Immunology and Immunopathology, 117, 249-253.

Guven, K., Mutlu, M.B., Gülbandılar, A., Cakır, P. (2010). Occurrence and characterization of Staphylococcus aureus isolated from meat and dairy products consumed in Turkey. Journal of Food Safety, 30, 196-212.

Hein, I., Lehner, A., Rieck, P., Klein, K., Brandl, E., Wagner, M. (2001). Comparison of different approaches to quantify Staphylococcus aureus cells by real-time quantitative PCR and application of this technique for examination of cheeses. Applied and Environmental Microbiology, 67, 3122-3126.

Holochová, P., Růžičková, V., Dostálová, L., Pantůček, R., Petráš, P., Doškař, J. (2010). Rapid detection and differentiation of the exfoliative toxin A-producing Staphylococcus aureus strains based on $\phi$ ETA prophage polymorphisms. Diagnostic Microbiology and Infectious Disease, 66, 248-252.

Huong, B.T.M., Mahmud, Z.H., Neogi, S.B., Kassu, A., Nhien, N.V., Mohammad, A., Yamato, M., Ota, F., Dao, N.T.L.H.T.A. and Khan, N.C. (2010). Toxigenicity and genetic diversity of Staphylococcus aureus isolated from Vietnamese ready-to-eat foods. Food Control, 21, 166-171.

Kabadjova, P., Dousset, X., Le Cam, V., Prevost, H. (2002). Differentiation of closely related Carnobacterium food isolates based on $16 \mathrm{~S}-23 \mathrm{~S}$ ribosomal DNA intergenic spacer region polymorphism. Applied and Environmental Microbiology, 68, 5358-5366.

Kateete, D.P., Kimani, C.N., Katabazi, F.A., Okeng, A., Okee, M.S., Nanteza, A., Joloba, M.L., Najjuka, F.C. (2010). Identification of Staphylococcus aureus: 
DNase and mannitol salt agar improve the efficiency of the tube coagulase test. Annals of Clinical Microbiology and Antimicrobials, 9, 23-29.

Kong, C., Neoh H., Nathan S. (2016). Targeting Staphylococcus aureus toxins: a potential form of anti-virulence therapy. Toxins (Basel), 8(3), 72.

Lem, P., Spiegelman, J., Toye, B. and Ramotar K. (2001). Direct detection of $\underline{m e c A}, \underline{n u c}$ and 16S rRNA genes in BacT/Alert blood culture bottles. Diagnostic Microbiology and Infectious Disease, 41, 165-168.

Malathi, J., Sowmiya, M., Margarita, S., Madhavan, H.N., Lily Therese, K. (2009). Application of PCR basedRFLP for species identification of ocular isolates of methicillin resistant Staphylococci (MRS). Indian Journal of Medical Research, 130, 78-84.

Mehrotra, M., Wang, G., Johnson, W.M. (2000). Multiplex PCR for detection of genes for Staphylococcus aureus enterotoxins, exfoliative toxins, toxic shock syndrome toxin 1, and methicillin resistance. Journal of Clinical Microbiology, 38, 1032-1035.

Miranda, J.M., Mondragón, A., Vázqueza, B.I., Fentea, C.A., Cepedaa, A., Francoa, C.M. (2009). Microbiological quality and antimicrobial resistance of Escherichia coli and Staphylococcus aureus isolated from conventional and organic "Arzúa-Ulloa" cheese. CyTA - Journal of Food. 7, 103-110.

Peles, F., Wagner, M., Varga, L., Hein, I., Rieck, P., Gutser, K., Keresztúri, P., Kardos, G., Turcsányi, I., Béri, B., Szabó, A. (2007). Characterization of Staphylococcus aureus strains isolated from bovine milk in Hungary. International Journal of Food Microbiology, 118, 186193.

Phuektes, P., Browning, G.F., Anderson, G., Mansel, P.D. (2003). Multiplex polymerase chain reaction as a mastitis screening test for Staphylococcus aureus, Streptococcus agalactiae, Streptococcus dysgalactiae, and Streptococcus uberis in bulk milk samples. Journal of Dairy Research, 70, 149-155.

Riyaz-Ul-Hassan, S., Verma, V., Qazi, G.N. (2008). Evaluation of three different molecular markers for the detection of Staphylococcus aureus by polymerase chain reaction. Food Microbiology, 25, 452-459.
Sperber W.H., Tatini S.R. (1975). Interpretation of the tube coagulase test for identification of Staphylococcus aureus. Applied Microbiology, 29(4), 502-505.

Straub, J.A., Hertel, C., Hammes, W.P. (1999). A 23S rRNA targeted polymerase chain reaction-based system for detection of Staphylococcus aureus in meat starter cultures and dairy products. Journal of Food Protection, $62,1150-1156$.

Stutz, K., Stephan, R., Tasara, T. (2011). SpA, ClfA, and $F n b A$ Genetic variations lead to staphaurex test-negative phenotypes in bovine mastitis Staphylococcus aureus isolates. Journal of Clinical Microbiology, 49, 638-646.

Sudagidan, M., Çavuşoğlu, C., Bacakoğlu, F. (2008). Investigation of the virulence genes in methicillin-resistant Staphylococcus aureus strains isolated from biomaterial surfaces. Mikrobiyoloji Bülteni, 42, 29-39.

Sudagidan, M., Aydin, A. (2010). Virulence properties of methicillin-susceptible Staphylococcus aureus food isolates encoding Panton-Valentine Leukocidin gene. International Journal of Food Microbiology, 138, 287291.

Tamura, K., Peterson, D., Peterson, N., Stecher, G., Nei, M., Kumar, S. (2011). MEGA5: Molecular evolutionary genetics analysis using maximum likelihood, evolutionary distance, and maximum parsimony methods. Molecular Biology and Evolution, 28, 2731-2739.

Tiwari, H.K., Sapkota, D., Sen, M.R. (2008). Evaluation of different tests for detection of Staphylococcus aureus using coagulase (coa) gene PCR as the gold standard. Nepal Medical College Journal, 10, 129-131.

Vandenesch, F., Lebeau, C., Bes, M., Mcdevitt, D., Greenland, T., Novickj, R.P., Etienne, J. (1994). Coagulase deficiency in clinical isolates of Staphyococcus aureus invoIves both transcriptional and post-transcriptional defects. Journal of Medical Microbiology, 40, 344-349.

Vasconcelos, N.G., Cunha, M.L.R.S. (2010). Staphylococcal enterotoxins: Molecular aspects and detection methods. Journal of Public Health and Epidemiology, 2, 29-42. 
Villarreal, M.L.M., Padilha, M., Vieira, A.D.S., Franco, B.D.G.M., Martinez, R.C.R., Saad, S.M.I. (2013). Advantageous direct quantification of viable closely related probiotics in petit-suisse cheeses under in vitro gastrointestinal conditions by propidium monoazideqPCR. PloS One, 8, 1-11.
Yucel, N. Citak, S., Bayhun, S. (2011). Antimicrobial resistance profile of Staphylococcus aureus isolated from clinical samples and foods of animal origin. Foodborne Pathogens and Disease, 8, 427-431. 